\title{
A short-term colorectal cancer sphere culture as a relevant tool for human cancer biology investigation
}

\author{
L-B Weiswald ${ }^{1,2,12}$, S Richon ${ }^{1,3}$, G Massonnet ${ }^{1,4}$, J-M Guinebretière ${ }^{5}$, S Vacher ${ }^{6}$, I Laurendeau ${ }^{3,7}$, P Cottu $^{4,8}$,
} $\mathrm{E}$ Marangoni ${ }^{4}$, F Nemati ${ }^{4}$, P Validire ${ }^{9}$, D Bellet ${ }^{2,10}$, I Bièche $e^{3,6,7}$ and V Dangles-Marie ${ }^{\star, 1,4,11}$

${ }^{1}$ IFR71 Sciences du Médicament, Faculté des Sciences Pharmaceutiques et Biologiques, Université Paris Descartes, Sorbonne Paris Cité, 4 Avenue de l'Observatoire, F-75006 Paris, France; ${ }^{2}$ Laboratoire d'Oncobiologie, Hôpital René Huguenin, Institut Curie, 35 Rue Dailly, F-92210 St Cloud, France; ${ }^{3}$ MTCE, Faculté des Sciences Pharmaceutiques et Biologiques, Université Paris Descartes, Sorbonne Paris Cité, 4 Avenue de l'Observatoire, F-75006 Paris, France; ${ }^{4}$ Laboratoire d'Investigation Préclinique, Département de Transfert, Centre de Recherche, Institut Curie, 26 Rue d'Ulm, F-75005 Paris, France; ${ }^{5}$ Service de Pathologie, Hôpital René Huguenin, Institut Curie, 35 Rue Dailly, F-92210 St Cloud, France; 'Laboratoire d'Oncogénétique, Hôpital René Huguenin, Institut Curie, 35 Rue Dailly, F-92210 St Cloud, France; ${ }^{7}$ UMR745 INSERM, Faculté des Sciences Pharmaceutiques et Biologiques, Université Paris Descartes, Sorbonne Paris Cité, 4 Avenue de l'Observatoire, F-75006 Paris, France; ${ }^{8}$ Département d'Oncologie Médicale, Institut Curie, 26 Rue d'Ulm, F-75005 Paris, France; ${ }^{9}$ Département d'Anatomie Pathologique, Institut Mutualiste Montsouris, 42 Boulevard Jourdan, F-75014 Paris, France; ${ }^{10}$ UMR 8151 CNRS-U1022 Inserm, Faculté des Sciences Pharmaceutiques et Biologiques, Université Paris Descartes, Sorbonne Paris Cité, 4 Avenue de l'Observatoire, F-75006 Paris, France and ${ }^{11}$ U932, Centre de Recherche, Institut Curie, 26 Rue d'Ulm, F-75005 Paris, France

Background: Ex vivo colospheres have been previously characterised as a colorectal cancer (CRC) well-rounded multicellular model, exclusively formed by carcinoma cells, and derived from fresh CRC tissue after mechanical dissociation. The ability to form colospheres was correlated with tumour aggressiveness. Their three-dimensional conformation prompted us to further investigate their potential interest as a preclinical cancer tool.

Methods: Patient-derived CRC xenografts were used to produce numerous colospheres. Mechanism of formation was elucidated by confocal microscopy. Expression analysis of a panel of 64 selected cancer-related genes by real-time qRT-PCR and hierarchical clustering allowed comparison of colospheres with parent xenografts. In vitro and in vivo assays were performed for migration and chemosensitivity studies.

Results: Colospheres, formed by tissue remodelling and compaction, remained viable several weeks in floating conditions, escaping anoikis through their strong cell-cell interactions. Colospheres matched the gene expression profile of the parent xenograft tissue. Colosphere-forming cells migrated in collagen I matrix and metastasised when subrenally implanted in nude mice. Besides, the colosphere responses to 5 -fluorouracil and irinotecan, two standard drugs in CRC, reproduced those of the in vivo original xenografts.

Conclusion: Colospheres closely mimic biological characteristics of in vivo CRC tumours. Consequently, they would be relevant ex vivo CRC models.

\footnotetext{
*Correspondence: Dr V Dangles-Marie; E-mail: virginie.dangles-marie@curie.fr

${ }^{12}$ Current address: Division of Gastroenterology, University of British Columbia, Vancouver, British Columbia, Canada, Genome Sciences Centre, British Columbia Cancer Agency, Vancouver, British Columbia, Canada V6T124.
}

Received 12 November 2012; revised 1 March 2013; accepted 5 March 2013; published online 28 March 2013 
Despite increasing knowledge about colorectal cancer (CRC) pathogenesis, this cancer disease remains a major cause of morbidity and mortality worldwide (Jemal et al, 2011). Colorectal cancer patient death is generally due to disease progression with metastasis development and resistance to chemotherapy. Complex factors involved in CRC metastasis remain largely undefined and there is still a cruel need for effective drugs for treatment. Future successful therapies must rely on a comprehensive analysis of events underlying the tumour progression and the metastatic processes, together with the development of new relevant model systems that could be easily manipulated in order to accurately evaluate the efficacy of novel agents and combinations.

In this context, the importance of studying cancer cells in threedimensional (3D) models has been emphasised because of their higher relevance to in vivo situation (Jacks and Weinberg, 2002; O'Brien et al, 2002; Yamada and Clark, 2002; Debnath and Brugge, 2005; Smalley et al, 2006; Yamada and Cukierman, 2007). Recent attention has focused on the need for better models that preserve the integrity of cancer stem cell (CSC) populations, as well as 3D microenvironmental interactions (Schmeichel and Bissell, 2003; Vaira et al, 2010; Gillet et al, 2011).

We had previously reported from a large clinical study the identification of ex vivo colospheres as a new colon cancer cell model (Weiswald et al, 2009). We have formerly demonstrated that this short-term culture model (i) cannot be obtained from normal colon tissue, (ii) is exclusively formed by epithelial cancer cells and (iii) is associated with tumour aggressiveness.

To further investigate the interest of colospheres as an ex vivo short-term culture tool for human colon cancer analysis and therapeutic testing, we used here CRC patient-derived tumour xenograft (PDX) models to work with a large quantity of reproducible biological material. Patient-derived tumour xenografts are established from human tumour fragments directly transplanted from patients into immunodeficient mice. These xenografts, obtained without in vitro manipulation, provide an accurate depiction of human tumour biological characteristics and are considered to represent the heterogeneity of human cancers (for review, see Tentler et al, 2012).

Fresh xenograft tissues give rise to numerous colospheres in a few days after mechanical dissociation in a reproducible way. We show that viable colospheres, through their strong cell-cell interactions, can be maintained in culture several weeks. As their gene expression profiles mimic the parent PDX tissue, colospheres could represent good candidates for modelling CRC ex vivo, which can be easily prepared and manipulated. In addition, the colosphere-forming cells also retain tumour aggressiveness properties. Finally, chemosensitivity assays based on colospheres demonstrate that the responses of this ex vivo model are similar to those of the in vivo original xenografts, illustrating one of the potential applications of colospheres as a short-term preclinical tool.

\section{MATERIALS AND METHODS}

Cell lines. The CT320 $\times 6$ cell line (passages P15-P25) was originally established from the XenoCT320 xenograft (DanglesMarie et al, 2007) and cultured in Dulbecco's modified Eagle medium (without phenol red) supplemented with $10 \%$ heat-inactivated fetal calf serum (Invitrogen, Cergy Pontoise, France), $10 \mathrm{mmoll}^{-1}$ Hepes, $4.5 \mathrm{gl}^{-1}$ glucose, $1 \mathrm{mmoll}^{-1}$ pyruvate sodium, 200 units $\mathrm{ml}^{-1}$ penicillin, $200 \mu \mathrm{g} \mathrm{ml}^{-1}$ streptomycin, referred as to 'culture medium'. The CT320 $\times 6$-GFP cell line was obtained by transduction with a LV-PGK-GFP lentiviral vector, kindly provided by Françoise Carlotti, Leiden University Medical Centre, The Netherlands, according to previous protocol (Carlotti et al, 2004). Viral supernatants were added to fresh medium supplemented with $8 \mu \mathrm{g} \mathrm{ml}^{-1}$ Polybrene (Sigma-Aldrich, Saint-Quentin Fallavier, France), and the cells were incubated overnight. The next day, the medium was replaced with fresh medium. Transduction efficiency was analysed 6 days post-transduction by cell sorting of GFP + cells using FACS Vantage dual laser flow cytometry (BD Biosciences, San Jose, CA, USA) and regularly controlled by flow cytometry.

Colon cancer xenografts. Colon cancer tumours had been obtained from patients after surgery. We had previously established the PDXs XenoCT316, XenoCT320, XenoCT336, XenoCT337 and XenoCT329 (Dangles-Marie et al, 2007) and the additional xenograft XenoCT1180 was similarly obtained from a colon primary tumour. The CR-LRB-010P, CR-LRB-011M, CR-IGR-007P, CR-IC-004M, CR-LRB-004P and CR-LRB-018P xenografts were established by the CReMEC consortium (Julien et al, 2012).

For xenograft passage (passages used here from P4 to P17), tumour fragments were subcutaneously grafted into 5-week-old athymic nude female mice (Harlan, Winkelmann, Germany) bred and maintained in specified pathogen-free conditions (protocol approval $\mathrm{n}^{\circ} \mathrm{P} 2$.VDM.026.07, local ethical committee on animal experiments, CREEA René Descartes, Paris, France). This protocol complies with the international $3 \mathrm{R}$ principle, more precisely in accordance with UKCCCR guidelines (Workman et al, 2010).

3D multicellular models. Two different 3D cancer cell models were used here: spheroids and colospheres. Spheroids referred as to multicellular tumour spheroids introduced by Sutherland in early 1970s (Sutherland, 1988). These spheroids are generated in vitro using permanent carcinoma cell lines in non-adherent conditions. As for colospheres, they are tissue-derived spheres, obtained directly by dissociation of CRC tissue. Protocols of preparation of these two models are depicted in Figure 1.

Spheroids from cancer cell lines. Three-dimensional multicellular spheroids were prepared by the liquid overlay technique as
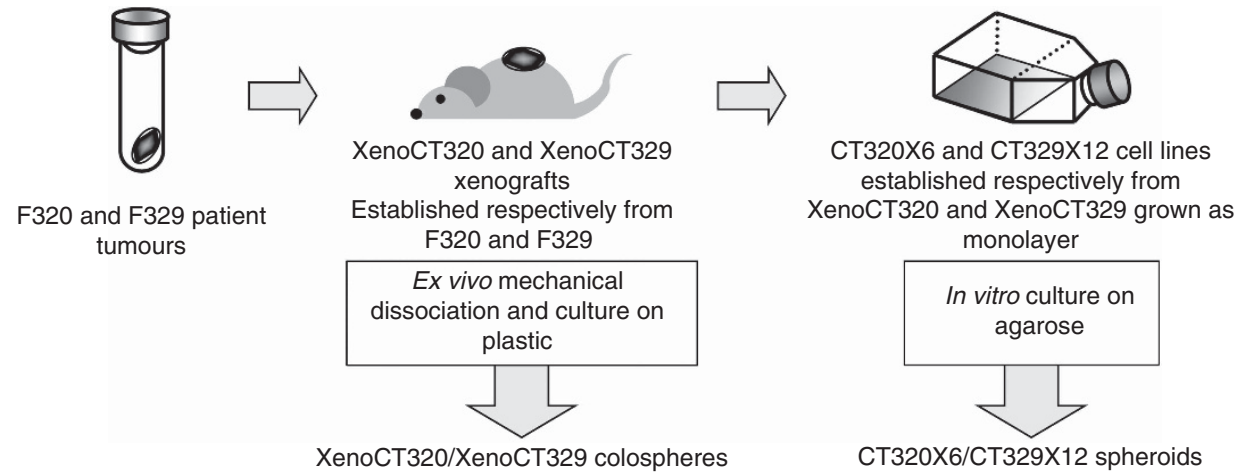

Figure 1. Protocol leading to the production of xenograft-derived colospheres and paired monolayers and spheroids. 
previously described (Dangles-Marie et al, 2007). In brief, tissue culture microplates were coated with $50 \mu \mathrm{l}$ of $1 \%$ agarose in water. Tumour cells grown as a monolayer were resuspended with trypsin, and $5.10^{3}$ cells were seeded in microwells so as to obtain, after 3 days, a single spheroid per well.

Colosphere obtained by ex vivo mechanical mincing. Mechanical dissociation protocol of tumour tissue has been previously described (Weiswald et al, 2009). Briefly, tumour tissue sample, after a medium washing step, was first finely cut with scalpel blade and crushed. The resulting pieces were transferred into a $25 \mathrm{~cm}^{2}$ culture flask in 'culture medium' and incubated at $37^{\circ} \mathrm{C}, 5 \% \mathrm{CO}_{2}$. Colospheres of $100-200 \mu \mathrm{m}$ in diameter were selected using cell strainers (Endecotts, London, England).

For colosphere formation mechanism study, $75 \mathrm{mg}$ of dissociated XenocT320 tissue (about $8.10^{4}$ live tumour cells) were incubated with $2.10^{5} \mathrm{CT} 320 \times 6 \mathrm{GFP}$ single cells per well of 12 -well cell culture plate at $37^{\circ} \mathrm{C}, 5 \% \mathrm{CO}_{2}$. After 3 days of co-culture, colospheres of all size were collected for confocal imaging.

Cell cycle analysis. Colospheres were dissociated by trypsinisation, fixed in cold $70 \%$ ethanol, treated with $20 \mu \mathrm{g} \mathrm{ml}^{-1}$ RNase for $30 \mathrm{~mm}$, incubated for $10 \mathrm{~mm}$ in $20 \mathrm{pg} \mathrm{mi}^{-1}$ propidium iodide (Sigma-Aldrich). Labelled cells were analysed by a FACsort (BD Biosciences, San Jose, CA, USA) and analysis was performed with MODFITLT software (Verity Software House, Topsham, ME, USA).

Cell-cell contact inhibition and apoptosis detection. Colospheres were incubated overnight with neutralising antihuman E-cadherin (clone SHE78-7, $10 \mu \mathrm{g} \mathrm{ml}^{-1}$; Invitrogen) or with 2 mM EDTA. Caspase- 3 activity was measured using luminescent assay Caspase-Glo 3/7 Assay (Promega, Charbonnières, France) and a VICTOR Multilabel Plate Reader (Perkin-Elmer, Courtabœuf, France), according to the manufacturer's instructions. Results are expressed as relative light units.

Collagen assay. Colospheres and spheroids were mixed with collagen I solution $\left(1 \mathrm{mg} \mathrm{ml}^{-1}\right.$, BD Biosciences, Le Pont de Claix, France) in 24-well plates before polymerisation of the lattice. Culture medium was added to the collagen layer and changed twice a week.

In vivo tumourigenicity assay. The tumourigenicity of Xeno CT320 colospheres and CT320×6 spheroids was compared in a subrenal capsule assay in nude mice as previously described (Weiswald et al, 2009). Briefly, in anaesthetised mice (xylazin/ ketamin protocol), injections of whole intact spheroids or colospheres were administered with a $27 \mathrm{G}$ needle in the subcapsular space in the right kidney. For analysis of local invasion, the equivalent of $10^{5}$ cells in $10 \mu \mathrm{l}$ was injected and the mice were killed 4 weeks later for kidney examination. For distant metastasis study, the equivalent of $4.10^{4}$ was injected and the mice were killed 14 weeks later. Colospheres of $100-200 \mu \mathrm{m}$ in diameter were collected and an aliquot was trypsinised to estimate the number of viable cells in the colospheres. The concentration was adjusted to have a number of colospheres equivalent to $4.10^{4}$ or $10^{5}$ cells per $10 \mu \mathrm{l}$ for subrenal capsule injection.

Similarly, 8 or 20 spheroids formed by seeding $5.10^{3}$ cells per microwell were injected in $10 \mu \mathrm{l}$. As spheroids from this cell line grow slowly, spheroids collected 3 days after initiation contained about 5000 cells per spheroid for a diameter of about $150 \mu \mathrm{m}$. The recipient mice were killed for gross examination and organs were removed for histological examination and/or RNA extraction.

Histological and immunofluorescence analyses. Colospheres or spheroids were embedded using the Cytoblock method (Briffod et al, 2000) and the Shandon kit (Thermo Electron Corporation, St Herblay, France) for haemalun-eosin and alcian blue staining. Immunostaining was performed on the resulting paraffin sections using an automated immunostainer (Ventana, Strasbourg, France), after antigen retrieval performed during $40 \mathrm{~min}$ in a water bath set at $95{ }^{\circ} \mathrm{C}-98^{\circ} \mathrm{C}$, followed by 20 -min cooling, with $\mathrm{mAb}$ to $\mathrm{Ki}-67$ antigen (MIB1 clone; 1:100 dilution; Dako, Trappes, France) or with anti-human $\beta$-catenin (14/ $\beta$-catenin clone; $1: 400$ dilution; BD Biosciences).

For triple staining on kidney sections, kidneys were transversely cross-sectioned, fixed for $2 \mathrm{~h}$ in phosphate-buffered saline (PBS) containing $4 \%$ paraformaldehyde (PFA; Euromedex, Mundolsheim, France) at $4{ }^{\circ} \mathrm{C}$ and stored in $2 \%$ PFA overnight at $4{ }^{\circ} \mathrm{C}$. Kidneys were embedded in $4 \%$ low melting point agarose (VWR International, Fontenay-sous-Bois, France) in preparation for vibratome sectioning. Transverse slices were cut at $50 \mu \mathrm{m}$ with a vibrating blade microtome (VT1000E; Leica Microsystems, Wetzlar, Germany) and carefully transferred to 48-well tissue culture plates in PBS. All incubations were performed on floating sections at room temperature (unless otherwise stated), under gentle rocking. After quenching of the aldehydes ( $1 \mathrm{~h}$ in PBS/ $\mathrm{NH} 4 \mathrm{Cl} 50 \mathrm{mmoll}^{-1}$ ), the sections were permeabilised for $1 \mathrm{~h}$ in PBS with 1\% Triton X-100 (Perbio Science, Brébières, France) and incubated for $2 \mathrm{~h}$ in blocking buffer (PBS with bovine serum albumin $1 \%$, goat serum $10 \%$ and Triton X-100 0.1\%). Sections were stained overnight at $4{ }^{\circ} \mathrm{C}$ with anti-human EpCAM (clone HEA-125) fluorescein isothiocyanate (1:100 dilution; MiltenyiBiotec SAS, Paris, France) and anti-human $\beta$-catenin (clone 15B8; $1: 100$ dilution; Abcam, Cambridge, UK) conjugated to Cy3 in PBS with Triton X-100 0.1\%. The DNA marker, TOPRO-3 (InvitrogenMolecular Probes, Cergy Pontoise, France) was then applied for $30 \mathrm{~min}\left(1 \mu \mathrm{moll}^{-1}\right)$. For colosphere staining, we used protocol previously described (Weiswald et al, 2010) with some modifications. Colospheres in suspension were fixed for $3 \mathrm{~h}$ at $4{ }^{\circ} \mathrm{C}$ in PBS containing $4 \%$ PFA and permeabilised in $0.5 \%$ Triton X-100 in PBS for $1 \mathrm{~h}$ at RT. After 1 - $\mathrm{h}$ incubation in PBS/NH4Cl $\left(50 \mathrm{mmol}^{-1}\right)$, filamentous actin was stained with Alexa Fluor 555 phalloidin (Invitrogen-Molecular Probes; $5 \mathrm{U} \mathrm{ml}^{-1}$ for $1 \mathrm{~h}$ ) and cell nuclei were counterstained with TOPRO-3 (1 $\mu \mathrm{moll}^{-1}$ for $40 \mathrm{~min}$ ). Kidney sections and colospheres were mounted in glycerol/PBS (90/10:v/v). Images were recorded on a Leica TCS SP2 confocal microscope (Leica Microsystems).

For flow cytometry analysis, colospheres were disaggregated using trypsin. Human CK20 staining (IT-Ks 20.10 clone, 1:50 dilution, Biovalley, Marne-La-Vallée, France) and human CDX2 (polyclonal antibody, \#3977, 1:50 dilution, Cell Signalling, St Quentin en Yvelines, France) were performed after cell fixation and permeabilisation. Labelled cells were analysed by a Guava easyCyte Flow Cytometer (Merck Millipore, Billerica, MA, USA) and analysis was performed with FLOWJO software (Tree Star, Ashland, OR, USA).

In vivo chemotherapy response in xenografts. Therapeutic assays were performed as previously described (Julien et al, 2012). Tumour fragments were subcutaneously xenografted in CB17SCID female mice (Charles River, L'Arbresle, France). When the mean tumour volume reached $100-200 \mathrm{~mm}^{3}$, mice were randomised to start the 5-FU (ICN, Orsay, France) or irinotecan (Campto; Pfizer, Paris, France) treatment with doses corresponding to $70 \%$ of the highest nontoxic dose: 5 -FU was intravenously administered ( $5 \mathrm{mg} \mathrm{kg}^{-1}$, two injections with a 4-day interval); irinotecan was intraperitoneally administered $\left(22 \mathrm{mg} \mathrm{kg}^{-1}\right.$, three administrations with a 2-day interval). $T / C=100 \times(T / C)=$ the percentage ratio between the mean tumour volume of a treated group $(T)$ and the mean tumour volume of the control group at a defined day.

Ex vivo cytotoxic assays on colospheres. Colospheres of 100-200 $\mu \mathrm{m}$ diameter were collected 3 days after tumour tissue dissociation and seeded into 96-well plates, precoated with $50 \mu \mathrm{l}$ of $1 \%$ agarose in water: 50 colospheres per well in $100 \mu \mathrm{l}$ of culture 
medium without pyruvate sodium. Irinotecan (Aventis, Vitry-surSeine, France) or 5-FU (Merck, Lyon, France) dilution (100 $\mu \mathrm{l})$ were added to sextuplate wells. After 3 days of exposure, cell cytotoxicity and viability in treated $v s$ control wells was estimated by lactate dehydrogenase and water-soluble tetrazolium assays respectively (Roche Diagnostics, Meylan, France) according to manufacturer's instructions. Data were reported as means \pm s.e.m. Dose-response curves were calculated for each individual experiment via sigmoidal dose-response analysis using the Hill fitting equation in the Prism 4 software (GraphPad Software Inc., San Diego, CA, USA).

Gene expression in tumour samples. RNA extraction, cDNA synthesis and PCR reaction conditions are described elsewhere (Bieche et al, 2001). To assess the precise amount of total RNA added to each reaction and its quality, we also quantified transcripts of the gene TBP (Genbank accession NM_003194) encoding for the TATA box-binding protein (a component of the DNA-binding protein complex TFIID) as an endogenous RNA control, and normalised each sample on the basis of its TBP content.

Results, expressed as $\mathrm{N}$-fold differences in target gene expression relative to the TBP gene, termed ' $N_{\text {target }}$ ', were determined by the formula: $N_{\text {target }}=2^{\Delta \text { Ctsample }}$, where $\Delta \mathrm{Ct}$ value of the sample was determined by subtracting the average $\mathrm{Ct}$ value of the target gene from the average Ct value of the TBP gene. The $N_{\text {target }}$ values of the samples were subsequently normalised such that the median of the parent PDX $N_{\text {target }}$ values was 1.

Primers for TBP (selected to amplify both the mouse and the human TBP genes) and the 64 target genes (selected to be specific of the human target sequences, Supplementary Table 1) were chosen with the assistance of the computer programmes Oligo 6.0 (National Biosciences, Plymouth, MN, USA). We conducted searches in dbEST and $\mathrm{nr}$ databases to confirm the total gene specificity of the nucleotide sequences chosen for the primers, and the absence of single-nucleotide polymorphisms. The nucleotide sequences of the oligonucleotide hybridisation primers are available on request. To avoid amplification of contaminating genomic DNA, one of the two primers was placed at the junction between two exons or on two different exons. For each human target primer pair, we performed mouse control (pooled ARNs of various mouse organs) assays, which produced negligible signals (usually $>40$ in Ct values), suggesting total human specificity of the 64 target primer pairs.

As the mRNA levels did not fit a Gaussian distribution, the mRNA levels in each subgroup of samples (six subgroups: XenoCT320, XenoCT329, XenoCT1180 xenografts and their paired colospheres) were characterised by their median and range rather than their mean and coefficient of variation.

The 64 selected genes were used for clustering analyses. Dendrograms classifying samples with centroid linkage methods using the Pearson correlation as a distance metric were obtained on the basis of the expression profile of quantitative RT-PCR with dchip 2010.01 (Li and Wong, 2001; http://biosun1.harvard.edu/ complab/dchip/). Genes were considered to be candidate genes associated with colospheres when they showed more than two-fold change in expression in colospheres compared with the parent PDX for each of the three models (XenoCT320, XenoCT329 and XenoCT1180). N-fold reported in Supplementary Table 1 is the median of the ratios between colospheres and parent PDX for at least three experiments, for each of the three models.

Detection of infra-histologic human micrometastatic lesions. Owing to the high specificity of the technique, the real-time PCR allows to distinguish human from mouse gene expression in xenograft models. The presence of few human cells within a host organ is quantified by mean of the transcript of human genes highly (to increase the sensibility) and exclusively represented in the human genome (Alu sequences). This method applied to the xenograft models greatly enhances the sensitivity of detection of invading human cells within kidney and lung tissues.

Results, expressed as N-fold differences in human Alu expression relative to the TBP genes (primers for $T B P$ were selected to amplify both the mouse and the human TBP genes), termed ' $N_{\text {Alu }}$ ', were determined by the formula: $N_{\text {Alu }}=2^{\Delta \text { Ctsample, }}$ where $\Delta \mathrm{Ct}$ value of the sample was determined by subtracting the average $\mathrm{Ct}$ value of the Alu sequences from the average $\mathrm{Ct}$ value of the TBP genes. Alu transcripts were considered to be detectable and quantifiable (with $N_{\text {Alu }}$ determination) when the Ct value was below 35, and not detectable when the Ct value was above 35 .

\section{RESULTS}

Cell viability preserved in colospheres. The ex vivo use of colospheres for cancer biology investigation requires that colospheres remained viable for the duration of the ex vivo experiments. To evaluate this viability, we used colospheres obtained from two patient-derived colon cancer xenografts, CR-LRB-018P and XenoCT320.

When colospheres were maintained on tissue-culture-treated flasks, they started quickly to attach to the flask plastic, as depicted in Figure 2A. Within 5 days after dissociation, individual cells migrated out to form a monolayer and after 8 days, the colosphere border totally disappeared. Consequently, we put them on agarose in order to prevent plastic attachment, and to maintain floating colospheres in culture. After 2 weeks in suspension culture, colospheres have been collected for Ki-67 staining and cell cycle analysis by propidium iodide staining. As revealed in Figure 2B, sphere structure and morphology are preserved up to 2 weeks. Cell cycle distribution analysis and anti-Ki-67 immunostaining clearly showed that colosphere-forming cells remained proliferative (Figures 2B and C).

Cell-cell contact required for colosphere viability. The importance of cell-cell contacts has been recently pointed out in a primary culture model close to ours (Kondo et al, 2011). Besides, our colospheres are very compact structures that cannot be dispersed by pipetting but require enzymatic treatment to be dissociated into single cells. These two features led us to investigate whether cell-cell interactions were necessary for survival of the colosphere-forming cells.

In the colosphere-forming assay, dispersed cells and fragments, resulting from mechanical tissue dissociation, are kept together in culture. After 3 days, colospheres are collected by pipetting for further analysis. We observed then that the remaining non-forming sphere cells, that is, single cells, did not survive (Figure 2D), suggesting that in the absence of cell-cell interactions, tumour cells cannot survive in this primary culture model. It is now well recognised that the malignancy of carcinoma cells relies on their ability to escape anoikis, a specialised form of apoptosis undergone by cells when adhesion to the correct substrate is disrupted (Eccles and Welch, 2007). To get more information here about the role of cell-cell interactions, we inhibited cadherin adhesion by incubating overnight colospheres with a blocking monoclonal antibody to E-cadherin or with EDTA, a calcium-chelating agent. In both cases, the treatments induced disaggregation of colospheres (Figure 2E), associated with a significant increase in the activity of caspase- 3 (Figure 2F).

Previous videomicroscopy analyses (Weiswald et al, 2009) had suggested that both cell adhesion and cell remodelling mechanisms may contribute to the fast formation of compact structures with strong cell-cell interactions, allowing cells to circumvent anoikis because of anchorage-independent growth. To further analyse these aggregation events, we incubated dissociated XenoCT320 
A D3

D5

D7

D8

D10

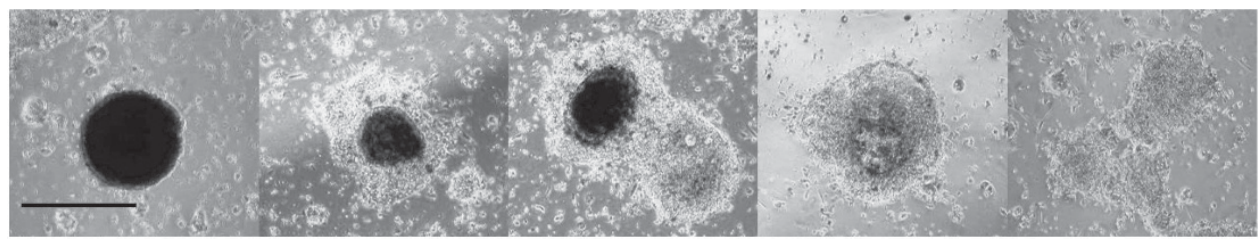

B

B
D3
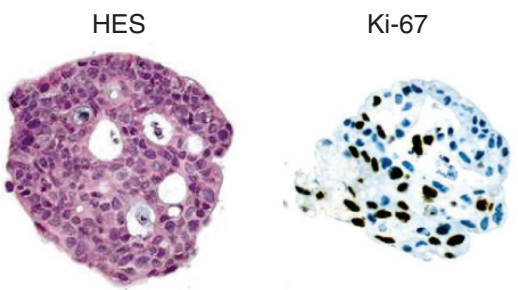

D17

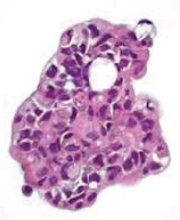

C

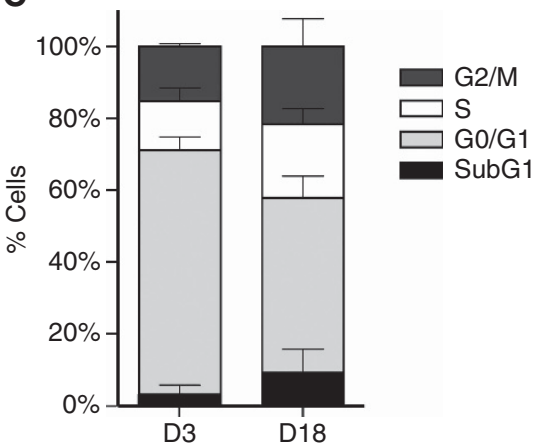

E

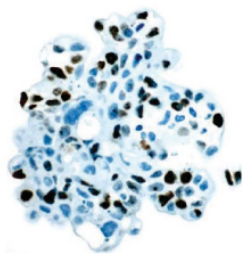

Anti-E-cadherin
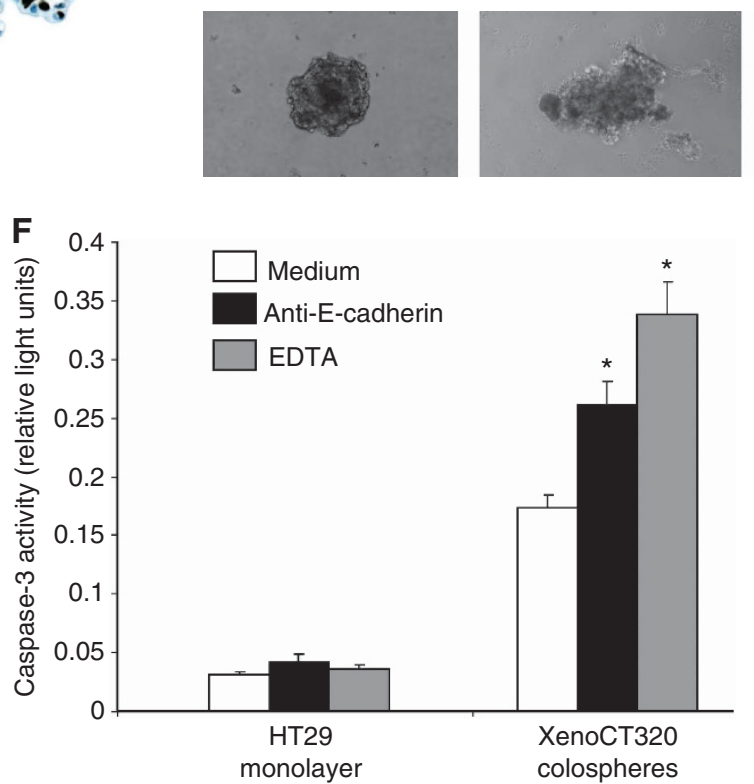

Figure 2. Colospheres are kept as a viable short-term 3D culture model in non-adherent conditions and resist anoikis as well-organised aggregates. (A) Colospheres maintained on tissue-culture-treated plastic form adherent cell sheets. Morphological changes were documented at day 3 (D3)-D10 after ex vivo dissociation. Bar: $200 \mu \mathrm{m}$. (B and C) Colospheres collected at D3 after tumour tissue dissociation are cultured for additional days on agarose to prevent adhesion to the plastic. (B) Haemalun-eosin-safran and anti-Ki-67 staining at D3 and D17. Magnification $\times 100$. (C) Cell cycle analysis by propidium iodide in XenoCT320 colosphere-forming cells at D3 (left) and D18 (right). The percentages for each cell cycle phase are presented as the mean \pm s.d. of at least three independent experiments. (D) Three days after tumour tissue dissociation, the nonforming colosphere cells are collected. Haemalun-eosin-safran (top) and pancytokeratin (bottom) staining show that these single epithelial cells are massively dead. Magnification $\times 200$. (E and F) Overnight incubated with anti-human E-cadherin or with EDTA lead to colosphere dispersion $(E)$ and significant increase in the caspase-3 activity $\left(F,{ }^{*} P<0.05\right.$, Student's t-test). Expression of caspase-3 activity as relative light units. HT29 monolayer is used to control the non-toxicity of EDTA concentration.

tissue with CT $320 \times 6$-GFP single cells. The human colon cancer cell line CT $320 \times 6$-GFP was derived from the CT $320 \times 6$ cell line, previously established from the XenoCT320 xenograft (DanglesMarie et al, 2007) and infected with lentivirus to produce GFP. The GFP + cells were sorted using cytometry (Figure 3A). After 3 days of co-culture, colospheres were collected for confocal imaging. GFP + cells were mostly present in small spheres $(<50 \mu \mathrm{m}$ in diameter) with some spheres formed only by GFP + cells
(Figure 3B). By contrast, bigger spheres had incorporated no or rare GFP + cells, only at the periphery (Figure 3C), which demonstrated remodelling of tumour fragments (i.e., modification in cell-cell interaction) seems to occur only in surface of colosphere. These observations confirm the existence of at least two mechanisms leading to colosphere formation: adhesion of single cells for small colospheres and remodelling of tumour fragments for the biggest ones. 
A
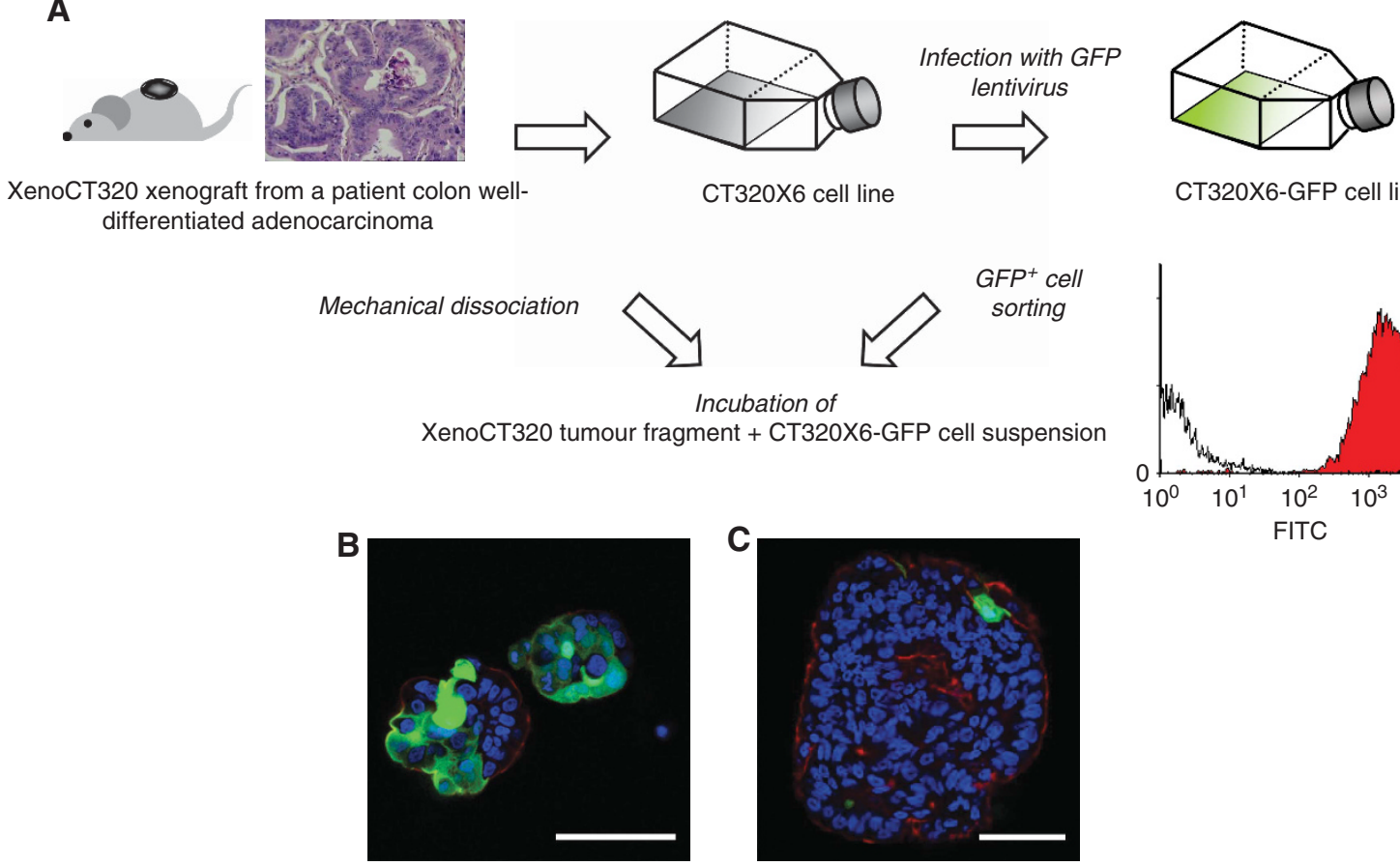

CT320X6-GFP cell line

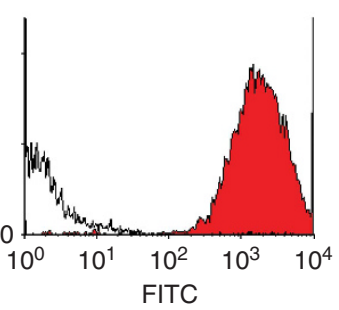

Figure 3. Single-cell adhesion and tissue remodelling mechanisms lead to colosphere formation. (A) Protocol of the co-incubation of dissociated XenoCT320 tissue with CT320×6-GFP single cells. Confocal immunofluorescence of derived small (B) and bigger colospheres (C). Visualisation of GFP in green, TOPRO-3 in blue (nuclei), AlexaFluor555-Phalloidin in red (F-actin). Scale bar: $50 \mu \mathrm{m}$.

Gene expression profiles of colospheres and PDXs. To determine whether the ex vivo conformational changes could modify tumour gene expression, we analysed the expression level of 64 selected genes for their involvement in cancer (Supplementary Table 1) in three colon PDXs, XenoCT320, XenoCT329 and XenoCT1180, and their derived colospheres. Absence of crossreactivity with mouse RNA has been checked using different mouse tissues. This species specificity allows the precise comparison of the gene expression profile of colospheres (formed only with cancer cells) and of cancer cells within PDX (PDXs consist of both human cancer cells and mouse stromal tissues). For each of the three models, we have performed real-time qRT-PCR with RNA extracted from at least two independent xenografts and their corresponding colospheres. All of the 64 genes tested presented detectable quantifiable mRNA expression $(\mathrm{Ct}>35)$.

A hierarchical clustering algorithm was used to organise the experimental samples only on the basis of overall similarity in their gene expression patterns. This clustering analysis of gene expression clearly demonstrated that for the three colon adenocarcinoma models, colospheres matched with their parent xenografts (Figure 4A), and showing that colospheres could mimic the in vivo tumour cells. In addition, as the morphological features of colospheres are close to those of spheroids, a well-defined multicellular 3D model generated in vitro using permanent carcinoma cell lines in non-adherent conditions (Friedrich et al, 2009), we compared here colospheres with spheroids obtained with the paired cell line (Figure 1 and Figures $4 \mathrm{~B}$ and C).

We found that for a given model (xenograft, derived colospheres and derived cancer cell lines cultured as monolayer or spheroids), cancer cell line models, in 2D or 3D conformation, clusterised together, distinctly from the xenograft and colospheres.

Then, we went on examining whether the colosphere structures would be reflected in a specific gene expression pattern. To select those genes that are consistently differentially expressed between colospheres and source xenografts, we calculated for each model and for each gene the ratio of transcript level in colospheres $v s$ in
PDX tissue. On the basis of a cutoff of 2, we obtained a list of three and five genes, which were respectively upregulated (ALDH1A1, BBC3/PUMA and ID2) or downregulated (MMP7, LGR5, NANOG, VIM and FLT1) in colospheres for the three models (Supplementary Table 1).

Colospheres as a potential model of tumour progression. We have previously demonstrated with primary colon tumours that the ability to form colospheres was related to the tumour aggressiveness (Weiswald et al, 2009). To further confirm and expand these findings, we used six colon PDXs directly established from three patient colon primary adenocarcinomas (XenoCT320, XenoCT336 and CR-LRB-010P) and their paired liver synchronous metastases (XenoCT316, XenoCT337 and CR-LRB-011M, respectively). These six PDXs were subcutaneously engrafted and harvested when they reached around $2000 \mathrm{~mm}^{3}$ in size. Each PDX was weighed and mechanically dissociated. Colospheres obtained 3 days after were counted and number of colospheres per mg of tumour tissues was calculated for each PDX. As shown in Figure 5A, the number of colospheres we obtained was significantly higher for tumour xenografts established from patient's metastasis than in the matched PDX established from the primary tumour in the three pairs (Student's $t$-test, $P<0.001$ ).

To further test the aggressiveness property of colospheres, we performed in vitro and in vivo invasive and migratory assays. XenoCT320 colospheres and CT $320 \times 6$ spheroids were embedded in collagen type I gels in the absence of a chemoattractant, incubated and followed by light microscopy. This extracellular matrix component was selected because in invasive regions with lack of basement membrane, colon cancer cells are known to interact directly with collagen type I (Brabletz et al, 2004). Although both colospheres and spheroids are strongly compacted aggregates, which cannot be dissociated by mechanical pipetting, single cells clearly succeeded in detaching from colospheres and migrate into the collagen matrix (Figure 5B). For spheroids, even if 


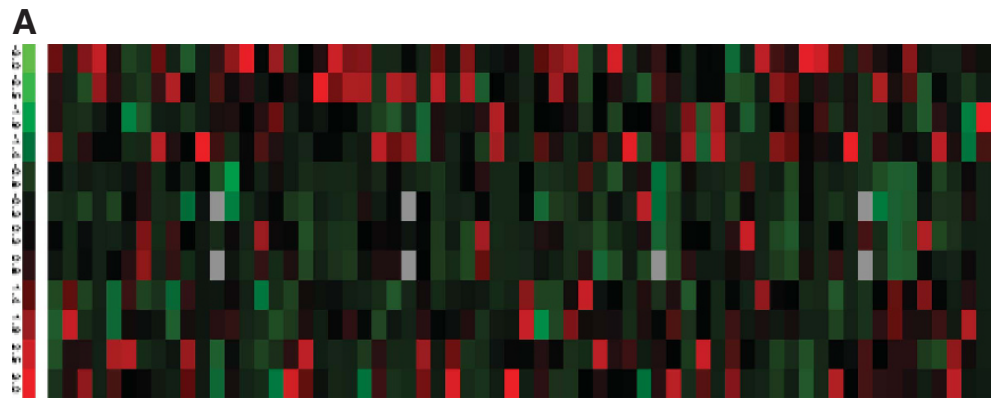

XenoCT320 (1)

XenoCT320 (2)

XenoCT320 colospheres (1)

XenoCT320 colospheres (2)

XenoCT329 (1)

XenoCT329 (2)

XenoCT329 colospheres (1)

XenoCT329 colospheres (2)

XenoCT1180 (1)

XenoCT1180 (2)

XenoCT1180 colospheres (1)

XenoCT1180 colospheres (2)

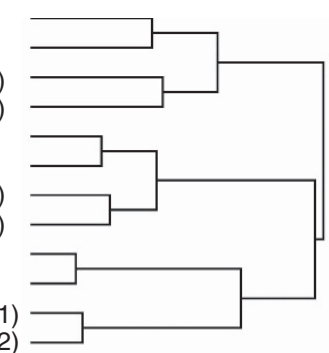

B

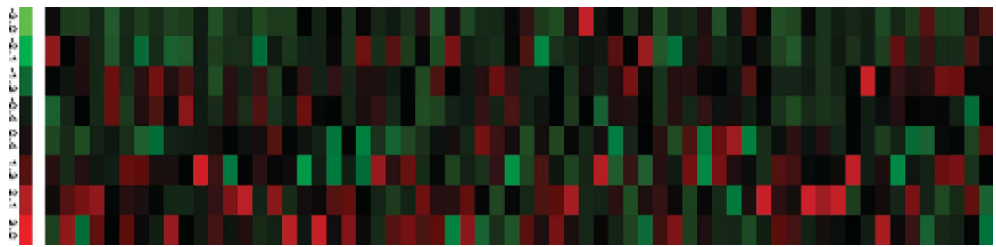

CT320X6 spheroids (1) СТ320X6 spheroids (2) CT320X6 monolayer (1) CT320X6 monolayer (2) XenoCT320 colospheres (1) XenoCT320 colospheres (2) XenoCT320 (1) XenoCT320 (2)
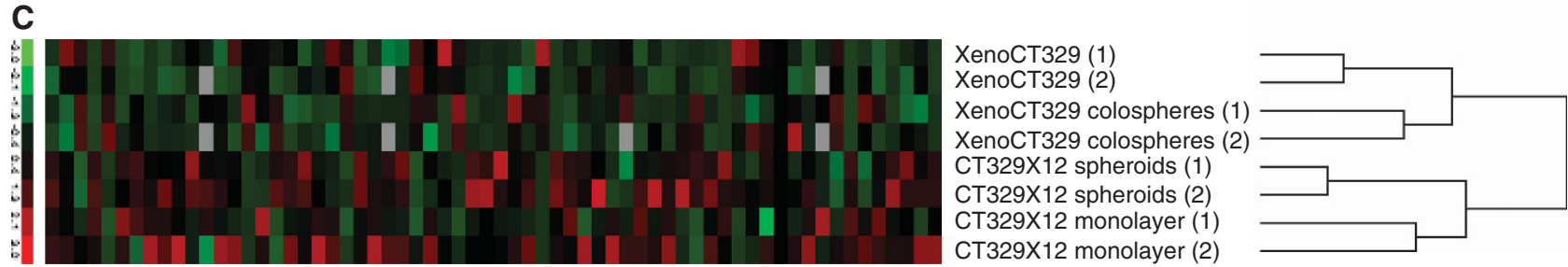

Figure 4. Colospheres closely match origin tumour tissue contrary to the paired cell lines cultured as spheroids or monolayers. (A) Hierarchical clustering based on the expression of 64 selected genes (listed in Supporting Information Supplementary Table S1) in colospheres and corresponding xenografts from XenoCT320, XenoCT329 and XenoCT1180 models. Two independent pairs of colospheres and parental xenograft tissue for each model are studied. (B and C) Hierarchical clustering based on the expression of the 64 genes in colospheres, the original xenograft, and the derived cell line studied as monolayer and spheroids is shown for (B) XenoCT320 system model and (C) XenoCT329 system model. Each column represents a gene. The expression index is standardised genewise to have mean 0 and s.d. 1 ( -3.0, green to +3.0 , red).

larger size of spheroid clusters was shown overtime, no invasive phenotype with isolated cells could be observed.

As invasive phenotype in colon cancer is associated with $\beta$-catenin expression (Brabletz et al, 2001), immunostaining of the original spheroids and colospheres (before collagen embedding) was performed. Beta-catenin was greatly expressed in both sphere models (Figure 5C). Nevertheless, although spheroid-forming cells showed a membrane-bound $\beta$-catenin, with only a few cells showing nuclear $\beta$-catenin localisation, cells within colospheres displayed nuclear expression of $\beta$-catenin, in line with their higher invasive potential.

In vivo local invasion properties of colospheres were tested through subrenal capsule implantation. Colospheres and spheroids were then studied in parallel: an equivalent number of human colon cancer cells $\left(10^{5}\right)$ as either colospheres derived from XenoCT320 xenograft or spheroids obtained by culturing CT $320 \times 6$ cell line on agarose were injected under the kidney capsule of five nude mice, respectively. Mice were killed 4 weeks later for kidney examination. Tumour formation at the injection site occurred in four out of five mice injected with XenoCT320 colospheres while only one mouse injected with CT $320 \times 6$ spheroids displayed tumour in kidney. In addition, histological examination clearly revealed two distinct patterns of local invasion (Figure 5D): colospheres gave rise to adenocarcinoma tumours infiltrating the kidney with rare necrosis in spite of the tumour size. By contrast, spheroids grew as a well-encapsulated carcinoma mass, with highly necrotic centre. Immunostaining against $\beta$ catenin showed heterogeneous staining in colosphere-induced adenocarcinoma, with highly nuclear expression in some cells surrounding the tumour whereas spheroid induced tumour displayed homogenous pattern expression.
Tumourigenicity and dissemination properties of colospheres were investigated by screening mouse organs for presence of human Alu RNA, an infra-anatomopathological test to detect human micrometastasis in engrafted animals. The repetitive character of human Alu-sequence RNA allows a highly sensitive detection and quantification of human disseminated viable tumour cells in xenograft mouse models using qRT-PCR. For this purpose, $4.10^{4}$ cells as either whole colospheres or spheroids were implanted in 30 mice (15 in each group), under the kidney capsule. Mice were killed and necropsied 14 weeks later. Macroscopic lesions were found only in the group of mice injected with colospheres: tumours at the kidney in six mice and one lung lesion were observed. Histological analysis confirmed that all these lesions were colon adenocarcinomas (Figure 6A). Kidneys and lungs with no gross lesion were collected for RNA extraction. The qRT-PCR analysis for Alu RNA presence showed that in the 'colosphere injected' group, four additional right kidneys and five lungs were positive. As for 'spheroid injected' group, five kidneys revealed the presence of Alu RNA but no trace of human RNA has been detected in lungs (Figure 6B), confirming that colospheres display a more aggressive phenotype than spheroids.

Chemosensitivity assays with ex vivo colospheres. Colospheres are composed of viable cancer cells and grow ex vivo. This led us to evaluate their response to irinotecan and 5-FU, two major drugs in CRC treatment. For this purpose, we selected four colon cancer xenografts according to their in vivo drug response profile: CR-LRB-004P and CR-IGR-007P were respectively high and low responder to 5-FU (Figure 7A) whereas CR-LRB-018P and CR-IC$004 \mathrm{M}$ were respectively high and low responder to irinotecan in nude mice (Figure 7B). 
A

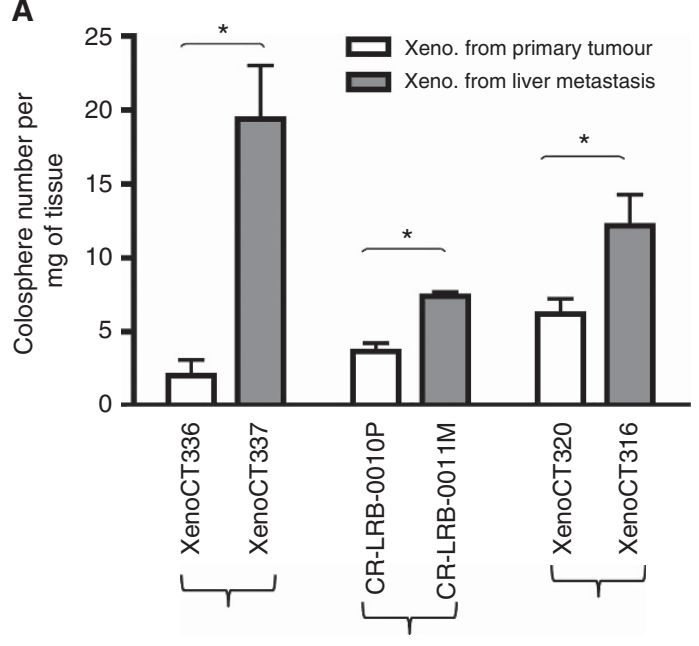

B

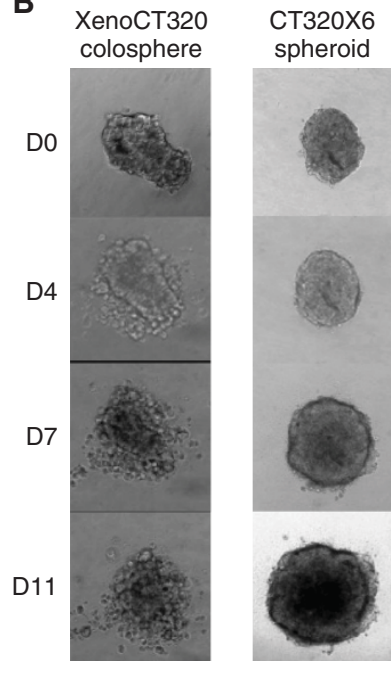

CT320X6 spheroid

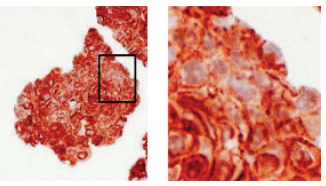

D
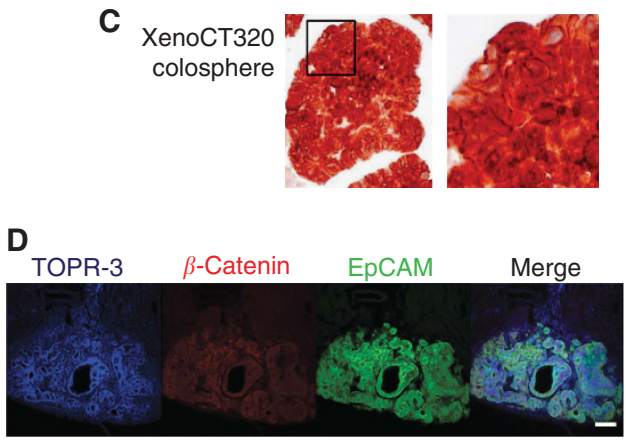

TOPRO-3 $\quad \beta$-Catenin EpCAM Merge
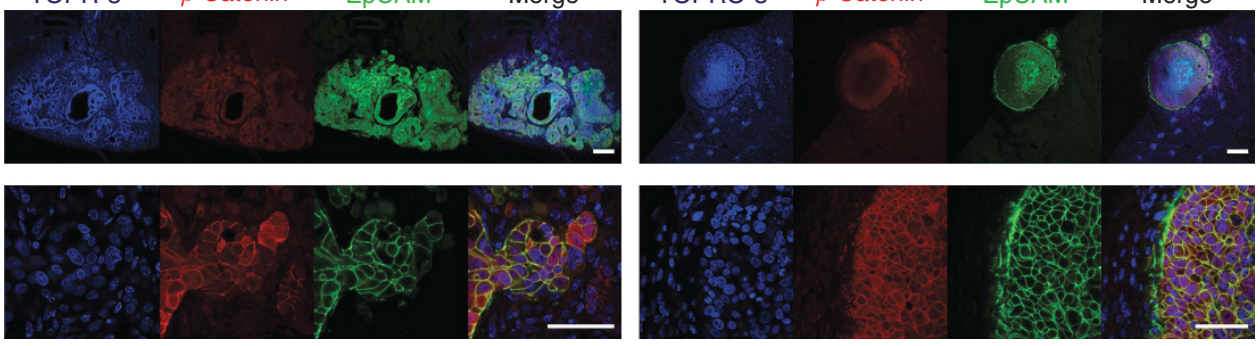

Figure 5. Aggressiveness properties of colospheres. (A) Number of colospheres per mg of tumour xenograft tissue, generated from three patient colon primary adenocarcinomas (white) and their paired liver synchronous metastases (grey). Data represent mean \pm s.d. of three experiments for each model ${ }^{*} P<0.05$. (B) XenoCT320 colospheres and CT320 66 spheroids were embedded in collagen I. Pictures were taken at days D0-D11 after embedding. (C) Anti- $\beta$-catenin immunostaining on XenoCT320 colospheres and CT320×6 spheroids in cytoblock assay. Magnification $\times 20$. At the right of each picture, higher magnification of the boxed area. (D) Colospheres and spheroids display in vivo distinct pattern of tumour development and $\beta$-catenin expression. Immunofluorescent staining of tumour section after kidney capsule injection of the equivalent number of human colon cancer cells $\left(10^{5}\right)$ of whole XenoCT320 colospheres (left) or whole CT320 6 spheroids (right). Human EpCAM and $\beta$-catenin were visualised in confocal microscopy. Nucleus counterstaining with TOPRO-3. Scale bar: upper panels, $200 \mu \mathrm{m}$. Lower panels, $50 \mu \mathrm{m}$.

Ex vivo chemosensitivity assay was performed on colospheres treated with different concentrations of 5-FU or irinotecan. The wide range of concentrations used for both agents allows to cover the peak concentrations observed in patient plasma (Chabot, 1997; Takimoto et al, 1999). Colosphere growth was inhibited dose dependently (Figure 7). In addition, ex vivo dose-response curves clearly differed between colospheres derived from in vivo highly sensitive xenografts and those obtained from poorly sensitive xenografts, with a discrepancy between IC50 values obtained either with colospheres from low- or high-responder xenografts in the two drugs assays: 5 -FU ( $>800 \mu \mathrm{M} v s 19.6 \pm 5.8 \mu \mathrm{M})$ and irinotecan $(424.7 \pm 93.7 \mu \mathrm{M} v s 23.8 \pm 5.8 \mu \mathrm{M})$.

\section{DISCUSSION}

We provide here new evidence that colospheres are a relevant tool for human cancer biology investigation, including metastatic process evaluation and chemosensitivity testing fields. Colospheres, formed only by carcinoma cells, are obtained in a very short time from fresh CRC tissue after mechanical dissociation in conventional culture conditions, as we have previously reported (Weiswald et al, 2009).

In order to be further easily manipulated, floating colosphere culture is required. Numerous colospheres were observed to adhere in a few days to the plastic. It is noteworthy that successful in vitro CRC cell line establishment is due to adhesion of these floating 3D multicellular aggregates (McBain et al, 1984; Park et al, 1987; Dangles-Marie et al, 2007). When kept in non-adherent conditions, the colosphere-forming cells remain viable and proliferating. The small size of the colospheres, $20-200 \mu \mathrm{m}$, is a well-known key factor for survival of 3D multicellular cancer model (Minchinton and Tannock, 2006; Vaira et al, 2010), allowing good diffusion of nutriments and oxygen and limiting necrosis phenomenon. Besides, it is now clearly recognised that the malignancy of carcinoma cells relies on their ability to escape anoikis (Eccles and Welch, 2007). We determined here that cell-cell contact in colospheres is indeed a key element for tumour cell survival because (i) single non-forming colosphere cells were unable to stay alive and (ii) inhibition of adhesion led to apoptosis. These results fit completely with the findings of Kondo et al (2011) in a very close model to ours, the 'colon tumour-originated spheroids', who 
A
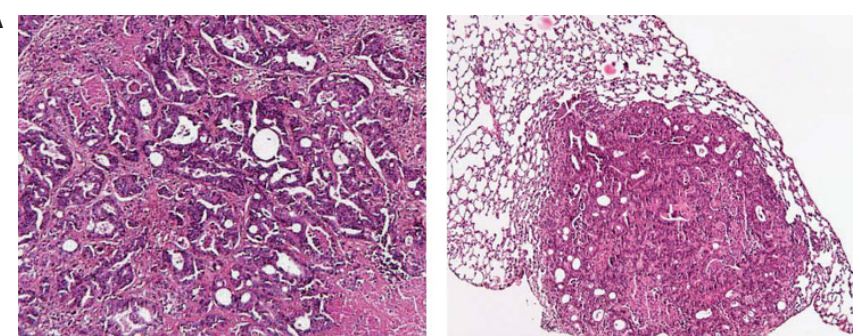

B

\begin{tabular}{|c|c|c|c|c|c|c|}
\hline \multirow{2}{*}{$\begin{array}{l}\text { Colon cancer cell } \\
\text { source }\end{array}$} & \multicolumn{3}{|c|}{ Kidney injection site } & \multicolumn{3}{|c|}{ Lung metastasis } \\
\hline & Total of positive mice & Macro & Alu & Total of positive mice & Macro & Alu \\
\hline XenoCT320 colospheres & $10 / 15$ & 6 & 4 & $6 / 15$ & 1 & 5 \\
\hline CT320X6 spheroids & $5 / 15$ & 0 & 5 & $0 / 15$ & 0 & 0 \\
\hline
\end{tabular}

Figure 6. XenoСT320 colospheres are tumourigenic and able to disseminate into mice. $4.10^{4}$ cells as either whole colospheres or whole spheroids were implanted in 2 groups of 15 nude mice, under the capsule of the right kidney. After 14 weeks, right kidneys and lungs were analysed for gross tumour lesions or presence of Alu-sequence RNA. (A) Macroscopic lesions were only observed in mice injected with colospheres. Histological analysis confirmed colon adenocarcinoma lesions in kidney (left) and in lung (right). Magnification $\times 12$. (B) Kidneys and lungs with no macroscopic lesion were collected for Alu RNA detection.

demonstrated also that their ex vivo colon cancer spheres resist anoikis as well-organised aggregates.

As the in vitro intestinal epithelial organoid protocols are generally based on crypt culture (Whitehead et al, 1999; Ootani et al, 2009; Chopra et al, 2010), colospheres could reflect crypt isolation through mechanical dissociation. Even if cytoblock slides of colospheres did not show a monolayer of polarised epithelial cells by contrast to the isolated crypts described in literature (Whitehead et al, 1999; Ootani et al, 2009; Chopra et al, 2010), compaction events could lead from a hollow to a plump structure. Furthermore, recent works from Clevers group (Sato et al, 2011) show that, distinct from mouse intestinal adenoma, human CRC organoids grew as compact structures with differentiated cells rather than a simple cystic structure. Study of relevant colon differentiation markers in colospheres showed high expression of CK20 and CDX2 and mucous cells stained with alcian blue (Supplementary Figure 1). It is noteworthy that along with Kondo et al (2011), we report no enrichment of CSC in ex vivo spheres.

Colospheres are formed at least by two types of mechanisms: aggregation of single cells for small colospheres and remodelling of tumour fragments for the bigger ones. The present mechanisms differ from those already described that led to CSC sphere formation like clonal expansion (Vermeulen et al, 2008) or fusion of blebbishields (Jinesh et al, 2013). Induction of 3D structure formation could be due to factor release. Indeed, when supernatants from dissociated XenoCT320 tissue culture were added on adherent colon cancer cell lines, we observed the formation of small compact floating clusters (Supplementary Figure 2). Interestingly, the same effect was obtained with supernatant from dissociated normal colon mucosa, while we had demonstrated that non-tumoural counterpart colon tissue is unable to form colospheres (Weiswald et al, 2009). Supernatants of colosphereforming xenografts have been also tested on dissociated non-colosphere-forming xenograft: no colosphere formation was observed (data not shown), suggesting that ability to generate colospheres is an intrinsic property of certain tumour cells. Consequently, generation of colospheres, at least small ones by cell aggregation, requires the presence of both released factors by tissue dissociation but also 'responsive' cells.

Gene expression analyses underlined that colospheres represent a culture of cancer cells whose profile globally mimics the solid tumour tissue profile, supporting the potential value of this model as an ex vivo tool. The clustering analysis demonstrated both the lack of ex vivo culture artefact (which would have led to classification into two groups: all xenografts opposed to all colospheres) and the relevance of colospheres for mimicking in vivo cancer cells within xenografts, in a closer way than paired cancer cell lines. We did not perform gene expression analysis directly on patient tumours and matched colospheres derived from these tumours. Nevertheless, gene expression analyses reported in the literature showed a strong similarity between the PDXs and their corresponding patient's tumours (Tentler et al, 2012). Among the human genes downregulated in xenografts with respect to patient's tumours, enrichment is generally observed in genes coding for extracellular matrix components, collagens and immune system regulators, in line with loss of human stroma, which is replaced by mouse stroma. Taken together, these gene expression data strongly suggested the ability of colospheres to recapitulate the gene expression profile of cancer cells in original patient tumours, and consequently their interest as reliable preclinical models.

Besides, among the 64 genes we selected for involvement in oncogenesis, expression of few genes ( 3 and 5 genes up or downregulated, respectively) are modified in cancer cells within colospheres $v s$ within parental xenograft tissues. Overexpression of ID2 and ALDH1A1 in colospheres is in favour of the presence of aggressive cells. No Id 2 staining was detected in normal colon mucosa (Rockman et al, 2001) but its expression in tumour cells is correlated with a poor prognosis (Gray, 2008): expression of Id2, a target of the $\beta$-catenin/T-cell factor pathway, was reported in $>40 \%$ of primary colon tumours and in almost all studied liver metastases (Rockman et al, 2001). Similarly, it was previously reported that colon carcinoma cells that were positive for ALDH1 tended to be present at the invasive front of colonic malignancies (Huang et al, 2009). ALDH1 protein expression was also found 
A
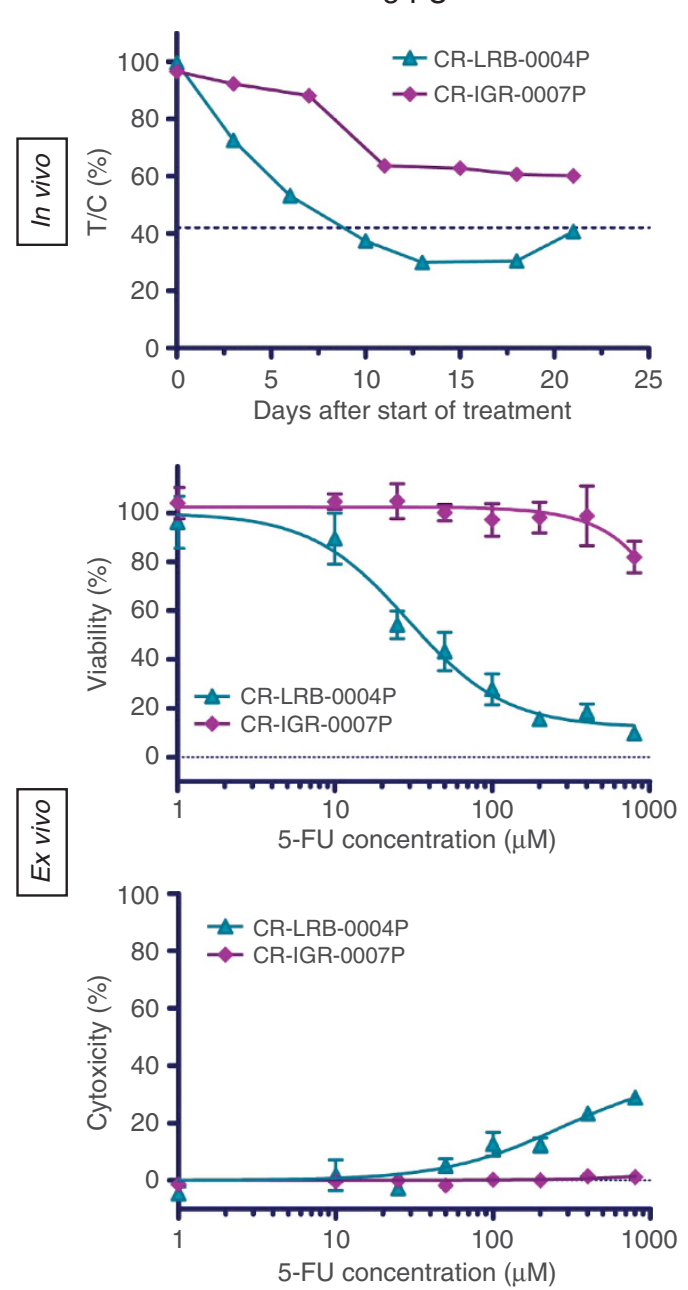

B
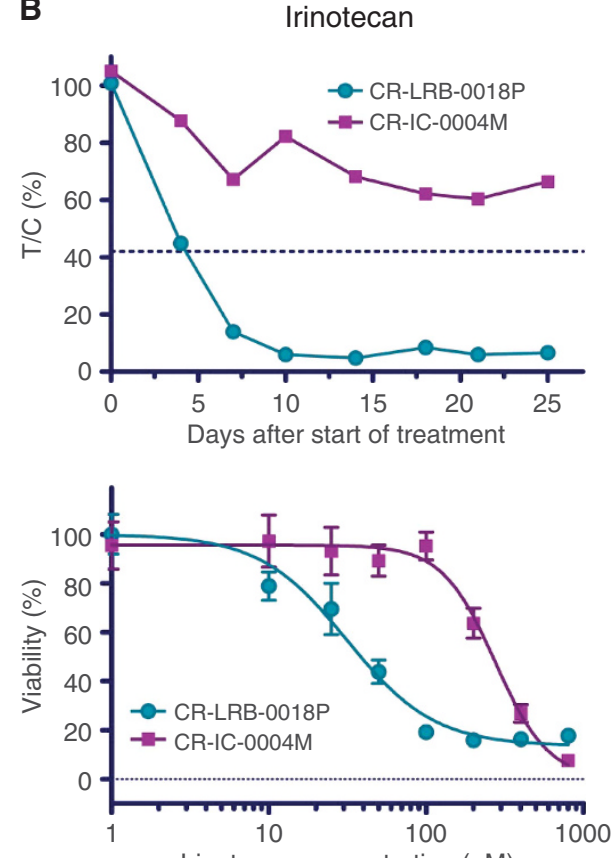

Irinotecan concentration $(\mu \mathrm{M})$

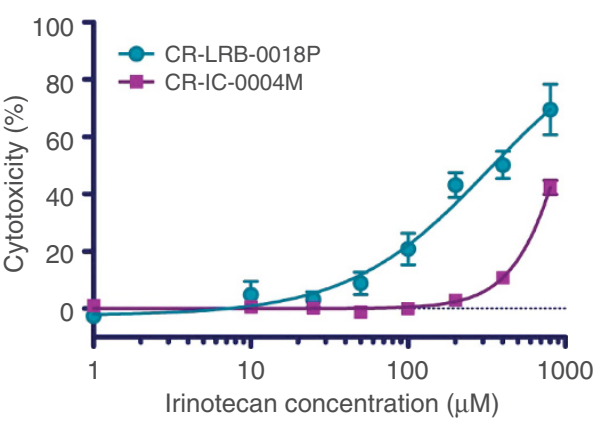

Figure 7. Colosphere chemosensitivity responses reflect in vivo parent colon PDX responses. (A) Effect of 5-FU on CR-IGR-007P (low responder) and CR-LRB-004P (high responder) colon cancer xenografts (in vivo) and paired colospheres viability and cytotoxicity (ex vivo graphs). (B) Effect of irinotecan on CR-IC-004M (low responder) and CR-LRB-018P (high responder) colon cancer xenografts (in vivo) and paired colospheres viability and cytotoxicity (ex vivo graphs). Data points are means \pm s.e.m. with 8-10 animals per group for in vivo experiments and with six-wells treated and measured per condition for ex vivo experiments. The results shown in ex vivo graphs are from one experiment taken as representative of, at least, three independent experiments.

correlated with ALDH enzymatic activity (Jiang et al, 2009), a crucial point as ALDH enzyme activity can be used as a functional marker for isolating CSCs (Carpentino et al, 2009; Huang et al, 2009). Nevertheless, other ALDH isoforms, particularly ALDH1A3, have been found more recently to significantly higher contribute to the tissue and cancer-specific aldefluor positivity (Marcato et al, 2011). Besides, this upregulation of ALDH1A1 has to be considered with the fact that expression of other 'colon stemness' genes PROM1, LGR5, CD44 and MSI1 was not increased. As for $B B C 3$ also known as PUMA, its overexpression could be related to stress induced by colosphere-forming assay. Indeed, mechanical stress is known to induce apoptosis via mitochondrial pathway (Cheng et al, 2009), which leads to rapid transcription of $B B C 3$ in human and mouse cells including CRC cells (Yu et al, 2001). Other gene expression profiles could appear unexpected. Indeed, matrylisin (MMP-7) is exclusively produced by cancer cells, unlike other MMPs, which are synthesised by stromal cells, and its expression is increased in human colorectal carcinomas, and correlates with malignant progression (Adachi et al, 1999). Nevertheless, although MMP7 is found here underexpressed in colospheres, its overexpression would be an early event in the adenoma-carcinoma pathway. MMP7 has been recently demonstrated to be required for tumour formation, but dispensable for invasion (Kitamura et al, 2009). Downexpression of NANOG, LGR5 (markers of stemness) and VIM (mesenchymal marker) could be put in line to each other because colosphere-forming cells maintained clearly their differentiation, without cancer stemness gene induction (Merlos-Suárez et al, 2011).

As for aggressive phenotype characterisation, collagen assays showed that colosphere-forming cells were able to detach from the spheres and to migrate into the matrix as single cells. On the other hand, colospheres have been shown to highly express $\beta$-catenin in cytoplasm together with a nuclear localisation; this expression is preserved in vivo after injection, not only at the invasive front, and could be related to their high capacity to infiltrate the engrafted kidney. According to the highly sensitive qRT-PCR approach, we developed for identification of micrometastasis using detection of Alu sequence RNA, we found out specifically trace of living human cancer cells in mouse lungs of $30 \%$ of engrafted animals with colospheres. These results showed the high potential of these $3 \mathrm{D}$ structures to grow and to disseminate in vivo, in a more aggressive way than the spheroids formed by cultured cell lines.

Preclinical cancer biology has traditionally relied on the use of human cancer cells lines cultured in vitro and of cell line-derived xenografts in immunodeficient mice. Considerable debate has focused on the reliability of such cell lines as cancer models 
(Johnson et al, 2001; Voskoglou-Nomikos et al, 2003). Emerging evidence suggests that the establishment of conventional cell lines from human cancer tissues results in irreversible loss of important biological properties (increase, reduction or even loss of expression of genes involved in cancer cell dissemination, CSC and so on; Daniel et al, 2009) and close resemblance between all the cell lines whatever their tumour type origin (Gillet et al, 2011).

All these data prompted us to consider whether the short-term culture of colon cancer tissue as small cellular 3D colospheres can be used to obtain information on the chemosensitivity of cancer cells. That colosphere-forming cells, with no enrichment of CSC, remain largely differentiated cells is not a drawback because the importance of cooperation between CSC and differentiated cells in drug resistance mechanisms has been recently reported (Emmink et $a l, 2011)$. Two conventional key chemotherapy drugs used to treat CRC, a topoisomerase I inhibitor, irinotecan, and an antimetabolite, 5-fluorouracil, have been chosen for these chemosensitivity assays. Based on both viability and cytotoxicity assays, we demonstrated here that colospheres can be applied to drug efficacy assays: in addition to a dose-dependent response, we showed for the first time with an ex vivo tumour model that colosphere response could reflect the responsiveness on parental cancer xenografts in nude mice to the same chemotherapy.

Finally, easy preparation with high yield and short-term culture of pure primary cancer cells as colospheres, preserving original cancer cell characteristics, provide an innovative platform for studying cancer biology and developing preclinical assays. Colosphere chemosensitivity assay, as a new, rapid, semi-automated and cost-effective assay, could be a complementary method in the anticancer drug pipeline, especially with drugs targeting directly cancer cells. Similarly, personalised medicine is an emerging issue in cancer treatment. Colospheres, obtained directly from patient colon tumours, could be similarly studied to determine their usefulness for evaluating the response of cancer cells to various drugs in predictive assays.

\section{ACKNOWLEDGEMENTS}

We thank the CReMEC consortium, especially Alain Bruno, Alain Pierré, Patricia Vrignaud, Cyril Berthet and Olivier Duchamp, for CReMEC patient-derived xenograft establishment and in vivo drug response characterisation. We are grateful to Claudine Le Ray for technical assistance in Cytoblock method, to Zofia Maciorowski for cell cycle analysis and to Chantal Martin and Isabelle Grandjean for housing and care of mice in the animal facility of IMTCE and Institut Curie, respectively. L-BW was supported by a predoctoral fellowship from the Association d'Aide à la Recherche Cancérologique de St Cloud and Association pour la Recherche sur le Cancer. This work was supported by grants from the Institut National du Cancer and Cancéropôle Ile de France ('COLOMETASTEM' and 'CSC cross platform network' projects); GEFLUC (Grant 5/188); Geneviève and Jean-Paul Driot Transformative Research Grant, Philippe and Denis Bloch Cancer Research Grant, Patrick Roy Translational Medicine Grant, Sally Paget-Brown Translational Research Grant.

\section{REFERENCES}

Adachi Y, Yamamoto H, Itoh F, Hinoda Y, Okada Y, Imai K (1999) Contribution of matrilysin (MMP-7) to the metastatic pathway of human colorectal cancers. Gut 45(2): 252-258.

Bieche I, Parfait B, Le Doussal V, Olivi M, Rio MC, Lidereau R, Vidaud M (2001) Identification of CGA as a novel estrogen receptor-responsive gene in breast cancer: an outstanding candidate marker to predict the response to endocrine therapy. Cancer Res 61(4): 1652-1658.
Brabletz T, Jung A, Reu S, Porzner M, Hlubek F, Kunz-Schughart LA, Knuechel R, Kirchner T (2001) Variable beta-catenin expression in colorectal cancers indicates tumor progression driven by the tumor environment. Proc Natl Acad Sci USA 98(18): 10356-10361.

Brabletz T, Spaderna S, Kolb J, Hlubek F, Faller G, Bruns CJ, Jung A, Nentwich J, Duluc I, Domon-Dell C, Kirchner T, Freund JN (2004) Down-regulation of the homeodomain factor $\mathrm{Cdx} 2$ in colorectal cancer by collagen type I: an active role for the tumor environment in malignant tumor progression. Cancer Res 64(19): 6973-6977.

Briffod M, Hacene K, Le Doussal V (2000) Immunohistochemistry on cell blocks from fine-needle cytopunctures of primary breast carcinomas and lymph node metastases. Mod Pathol 13(8): 841-850.

Carlotti F, Bazuine M, Kekarainen T, Seppen J, Pognonec P, Maassen JA, Hoeben RC (2004) Lentiviral vectors efficiently transduce quiescent mature 3T3-L1 adipocytes. Mol Ther 9(2): 209-217.

Carpentino JE, Hynes MJ, Appelman HD, Zheng T, Steindler DA, Scott EW, Huang EH (2009) Aldehyde dehydrogenase-expressing colon stem cells contribute to tumorigenesis in the transition from colitis to cancer. Cancer Res 69(20): 8208-8215.

Chabot GG (1997) Clinical pharmacokinetics of irinotecan. Clin Pharmacokinet 33(4): 245-259.

Cheng G, Tse J, Jain RK, Munn LL (2009) Micro-environmental mechanical stress controls tumor spheroid size and morphology by suppressing proliferation and inducing apoptosis in cancer cells. PLoS One 4(2): e4632.

Chopra DP, Dombkowski AA, Stemmer PM, Parker GC (2010) Intestinal epithelial cells in vitro. Stem Cells Dev 19(1): 131-142.

Dangles-Marie V, Pocard M, Richon S, Weiswald LB, Assayag F, Saulnier P, Judde JG, Janneau JL, Auger N, Validire P, Dutrillaux B, Praz F, Bellet D, Poupon MF (2007) Establishment of human colon cancer cell lines from fresh tumors versus xenografts: comparison of success rate and cell line features. Cancer Res 67(1): 398-407.

Daniel VC, Marchionni L, Hierman JS, Rhodes JT, Devereux WL, Rudin CM, Yung R, Parmigiani G, Dorsch M, Peacock CD, Watkins DN (2009) A primary xenograft model of small-cell lung cancer reveals irreversible changes in gene expression imposed by culture in vitro. Cancer Res 69(8): 3364-3373.

Debnath J, Brugge JS (2005) Modelling glandular epithelial cancers in three-dimensional cultures. Nat Rev Cancer 5(9): 675-688.

Eccles SA, Welch DR (2007) Metastasis: recent discoveries and novel treatment strategies. Lancet 369(9574): 1742-1757.

Emmink BL, Van Houdt WJ, Vries RG, Hoogwater FJ, Govaert KM, Verheem A, Nijkamp MW, Steller EJ, Jimenez CR, Clevers H, Borel Rinkes IH, Kranenburg O (2011) Differentiated human colorectal cancer cells protect tumor-initiating cells from irinotecan. Gastroenterology 141(1): 269-278.

Friedrich J, Seidel C, Ebner R, Kunz-Schughart LA (2009) Spheroid-based drug screen: considerations and practical approach. Nat Protoc 4(3): 309-324.

Gillet JP, Calcagno AM, Varma S, Marino M, Green LJ, Vora MI, Patel C, Orina JN, Eliseeva TA, Singal V, Padmanabhan R, Davidson B, Ganapathi R, Sood AK, Rueda BR, Ambudkar SV, Gottesman MM (2011) Redefining the relevance of established cancer cell lines to the study of mechanisms of clinical anti-cancer drug resistance. Proc Natl Acad Sci USA 108(46): $18708-18713$.

Gray MJ (2008) Therapeutic targeting of Id2 reduces growth of human colorectal carcinoma in the murine liver. Oncogene 27(57): 7192-7200.

Huang EH, Hynes MJ, Zhang T, Ginestier C, Dontu G, Appelman H, Fields JZ, Wicha MS, Boman BM (2009) Aldehyde dehydrogenase 1 is a marker for normal and malignant human colonic stem cells (SC) and tracks SC overpopulation during colon tumorigenesis. Cancer Res 69(8): 3382-3389.

Jacks T, Weinberg RA (2002) Taking the study of cancer cell survival to a new dimension. Cell 111(7): 923-925.

Jemal A, Bray F, Center MM, Ferlay J, Ward E, Forman D (2011) Global cancer statistics. CA Cancer J Clin 61(2): 69-90.

Jiang T, Collins BJ, Jin N, Watkins DN, Brock MV, Matsui W, Nelkin BD, Ball DW (2009) Achaete-scute complex homologue 1 regulates tumorinitiating capacity in human small cell lung cancer. Cancer Res 69(3): 845-854.

Jinesh GG, Choi W, Shah JB, Lee EK, Willis DL, Kamat AM (2013) Blebbishields, the emergency program for cancer stem cells: sphere formation and tumorigenesis after apoptosis. Cell death and differentiation 20(3): 382-395.

Johnson JI, Decker S, Zaharevitz D, Rubinstein LV, Venditti JM, Schepartz S, Kalyandrug S, Christian M, Arbuck S, Hollingshead M, Sausville EA 
(2001) Relationships between drug activity in NCI preclinical in vitro and in vivo models and early clinical trials. Br J Cancer 84(10): 1424-1431.

Julien S, Merino-Trigo A, Lacroix L, Pocard M, Goere D, Mariani P, Landron S, Bigot L, Nemati F, Dartigues P, Weiswald LB, Lantuas D, Morgand L, Pham E, Gonin P, Dangles-Marie V, Job B, Dessen P, Bruno A, Pierre A, De The H, Soliman H, Nunes M, Lardier G, Calvet L, Demers B, Prevost G, Vrignaud P, Roman-Roman S, Duchamp O, Berthet C (2012) Characterization of a large panel of patient-derived tumor xenografts representing the clinical heterogeneity of human colorectal cancer. Clin Cancer Res 18(19): 5314-5328.

Kitamura T, Biyajima K, Aoki M, Oshima M, Taketo MM (2009) Matrix metalloproteinase 7 is required for tumor formation, but dispensable for invasion and fibrosis in SMAD4-deficient intestinal adenocarcinomas. Lab Invest 89(1): 98-105.

Kondo J, Endo H, Okuyama H, Ishikawa O, Iishi H, Tsujii M, Ohue M, Inoue M (2011) Retaining cell-cell contact enables preparation and culture of spheroids composed of pure primary cancer cells from colorectal cancer. Proc Natl Acad Sci USA 108(15): 6235-6240.

Li C, Wong WH (2001) Model-based analysis of oligonucleotide arrays: expression index computation and outlier detection. Proc Natl Acad Sci USA 98(1): 31-36.

Marcato P, Dean CA, Giacomantonio CA, Lee PW (2011) Aldehyde dehydrogenase: its role as a cancer stem cell marker comes down to the specific isoform.. Cell Cycle 10(9): 1378-1384.

McBain JA, Weese JL, Meisner LF, Wolberg WH, Willson JK (1984) Establishment and characterization of human colorectal cancer cell lines. Cancer Res 44(12 Pt 1): 5813-5821.

Merlos-Suárez A, Barriga FM, Jung P, Iglesias M, Céspedes MV, Rossell D, Sevillano M, Hernando-Momblona X, da Silva-Diz V, Muñoz P, Clevers H, Sancho E, Mangues R, Batlle E (2011) The intestinal stem cell signature identifies colorectal cancer stem cells and predicts disease relapse. Cell Stem Cell 8(5): 511-524.

Minchinton AI, Tannock IF (2006) Drug penetration in solid tumours. Nat Rev Cancer 6(8): 583-592.

O'Brien LE, Zegers MM, Mostov KE (2002) Opinion: building epithelial architecture: insights from three-dimensional culture models. Nat Rev Mol Cell Biol 3(7): 531-537.

Ootani A, Li X, Sangiorgi E, Ho QT, Ueno H, Toda S, Sugihara H, Fujimoto K, Weissman IL, Capecchi MR, Kuo CJ (2009) Sustained in vitro intestinal epithelial culture within a Wnt-dependent stem cell niche. Nat Med 15(6): 701-706.

Park JG, Oie HK, Sugarbaker PH, Henslee JG, Chen TR, Johnson BE, Gazdar A (1987) Characteristics of cell lines established from human colorectal carcinoma. Cancer Res 47(24 Pt 1): 6710-6718.

Rockman SP, Currie SA, Ciavarella M, Vincan E, Dow C, Thomas RJ, Phillips WA (2001) Id2 is a target of the beta-catenin/T cell factor pathway in colon carcinoma. J Biol Chem 276(48): 45113-45119.

Sato T, Stange DE, Ferrante M, Vries RG, Van Es JH, Van den Brink S, Van Houdt WJ, Pronk A, Van Gorp J, Siersema PD, Clevers H (2011) Long-term expansion of epithelial organoids from human colon, adenoma, adenocarcinoma, and Barrett's epithelium. Gastroenterology 141(5): 1762-1772.

Schmeichel KL, Bissell MJ (2003) Modeling tissue-specific signaling and organ function in three dimensions. J Cell Sci 116(Pt 12): 2377-2388.
Smalley KS, Lioni M, Herlyn M (2006) Life isn't flat: taking cancer biology to the next dimension. In Vitro Cell Dev Biol Anim 42(8-9): 242-247.

Sutherland RM (1988) Cell and environment interactions in tumor microregions: the multicell spheroid model. Science 240(4849): 177-184.

Takimoto CH, Yee LK, Venzon DJ, Schuler B, Grollman F, Chabuk C, Hamilton JM, Chen AP, Allegra CJ, Grem JL (1999) High inter- and intrapatient variation in 5-fluorouracil plasma concentrations during a prolonged drug infusion. Clin Cancer Res 5(6): 1347-1352.

Tentler JJ, Tan AC, Weekes CD, Jimeno A, Leong S, Pitts TM, Arcaroli JJ, Messersmith WA, Eckhardt SG (2012) Patient-derived tumour xenografts as models for oncology drug development. Nat Rev Clin Oncol 9(6): 338-350.

Vaira V, Fedele G, Pyne S, Fasoli E, Zadra G, Bailey D, Snyder E, Faversani A, Coggi G, Flavin R, Bosari S, Loda M (2010) Preclinical model of organotypic culture for pharmacodynamic profiling of human tumors.. Proc Natl Acad Sci USA 107(18): 8352-8356.

Vermeulen L, Todaro M, de Sousa Mello F, Sprick MR, Kemper K, Perez Alea M, Richel DJ, Stassi G, Medema JP (2008) Single-cell cloning of colon cancer stem cells reveals a multi-lineage differentiation capacity.. Proc Natl Acad Sci USA 105(36): 13427-13432.

Voskoglou-Nomikos T, Pater JL, Seymour L (2003) Clinical predictive value of the in vitro cell line, human xenograft, and mouse allograft preclinical cancer models. Clin Cancer Res 9(11): 4227-4239.

Weiswald LB, Guinebretiere JM, Richon S, Bellet D, Saubamea B, DanglesMarie V (2010) In situ protein expression in tumour spheres: development of an immunostaining protocol for confocal microscopy. BMC Cancer 10: 106.

Weiswald LB, Richon S, Validire P, Briffod M, Lai-Kuen R, Cordelieres FP, Bertrand F, Dargere D, Massonnet G, Marangoni E, Gayet B, Pocard M, Bieche I, Poupon MF, Bellet D, Dangles-Marie V (2009) Newly characterised ex vivo colospheres as a three-dimensional colon cancer cell model of tumour aggressiveness. Br J Cancer 101(3): 473-482.

Whitehead RH, Demmler K, Rockman SP, Watson NK (1999) Clonogenic growth of epithelial cells from normal colonic mucosa from both mice and humans. Gastroenterology 117(4): 858-865.

Workman P, Aboagye EO, Balkwill F, Balmain A, Bruder G, Chaplin DJ, Double JA, Everitt J, Farningham DA, Glennie MJ, Kelland LR, Robinson V, Stratford IJ, Tozer GM, Watson S, Wedge SR, Eccles SA. Committee of the National Cancer Research I (2010) Guidelines for the welfare and use of animals in cancer research.. Br J Cancer 102(11): 1555-1577.

Yamada KM, Clark K (2002) Cell biology: survival in three dimensions. Nature 419(6909): 790-791.

Yamada KM, Cukierman E (2007) Modeling tissue morphogenesis and cancer in 3D. Cell 130(4): 601-610.

Yu J, Zhang L, Hwang PM, Kinzler KW, Vogelstein B (2001) PUMA induces the rapid apoptosis of colorectal cancer cells. Mol Cell 7(3): 673-682.

This work is published under the standard license to publish agreement. After 12 months the work will become freely available and the license terms will switch to a Creative Commons AttributionNonCommercial-Share Alike 3.0 Unported License.

Supplementary Information accompanies this paper on British Journal of Cancer website (http://www.nature.com/bjc) 